\title{
Focus on fluid therapy and nutritional support
}

\author{
Yaseen M. Arabi ${ }^{1 *}$ (1) and Anders Perner ${ }^{2}$
}

(c) 2018 Springer-Verlag GmbH Germany, part of Springer Nature and ESICM

Recent studies have challenged several widely accepted concepts in fluid and nutritional management. A series of articles in Intensive Care Medicine reflect the ongoing debate and areas of uncertainty.

How much intravenous fluid should be administered to patients with sepsis and hypotension or hyperlactatemia? A fixed $30 \mathrm{~mL} / \mathrm{kg}$ as recommended by the Surviving Sepsis Campaign guidelines [1, 2], or an individualized amount, perhaps $250-500 \mathrm{~mL}$ boluses followed by reassessments of the circulatory response? [3] There are no randomized trials comparing these two strategies [2]. The supporters of the fixed $30 \mathrm{~mL} / \mathrm{kg}$ of fluid suggest that this would be sufficient to correct hypovolemia in most patients without harm [2]. The $30 \mathrm{~mL} / \mathrm{kg}$ is not meant to negate an individualized assessment as some patients may need more fluids [2]. Observational data suggest that this strategy of fluid resuscitation is associated with reduced mortality [2]. In addition, using a protocol of a fixed minimum amount of fluids may facilitate wide implementation as assessment of fluid responsiveness may not occur in many clinical settings [2]. The opposite view suggests that such an approach ignores the complex circulatory failure in sepsis in which hypovolemia is combined with vasodilatation and myocardial depression [3]. In addition, there is increasing evidence for harm associated with excessive fluid administration [3]. Instead, a thorough clinical assessment and, in selected patients, more advanced hemodynamic monitoring will better identify those who will benefit from fluids, vasopressors, or inotropes [3]. The results of the FEAST (Fluid

*Correspondence: Arabi@ngha.med.sa

${ }^{1}$ Intensive Care Department, King Abdulaziz Medical City, College of Medicine, King Saud Bin Abdulaziz University for Health Sciences and King Abdullah International Medical Research Center, MC 1425, P.O. Box 22490, 11426 Riyadh, Saudi Arabia

Full author information is available at the end of the article
Expansion as Supportive Therapy) trial are often considered $[3,4]$. The trial showed increased mortality with albumin or saline boluses compared to no fluid boluses [4]. However, FEAST was conducted in African children, many of whom had malaria and severe anemia with no or minimal access to mechanical ventilation [2]. Therefore, the results of FEAST may not be generalizable to adult patients with sepsis [2].

In addition to the debate regarding the amount of resuscitation fluid, the clinical benefit of hydroxyethyl starch (HES) has been an area for extensive debate. In 2013, the European Medicines Agency published a decision of the European Commission that HES solutions must no longer be used to treat patients with sepsis or burns or critically ill patients because of an increased risk of kidney injury and mortality, although HES would be available in other selected indications [5-8]. Since then the consumption of HES has declined not only in ICUs but also in anesthesia and emergency departments [9]. But is the controversy over? Three articles in Intensive Care Medicine in 2017 addressed different aspects of this debate [8-10]. Evidence for harm includes data demonstrating increased risk of acute kidney injury with HES in surgical and non-surgical ICU patients, and in patients with sepsis [10]. In addition, HES has been associated with an increased risk of bleeding in patients with sepsis and those undergoing major surgery [10]. Most concerning are the data from meta-analyses in critically ill patients demonstrating increased mortality with HES [10]. However, the issue may be more complex [11]. It has been suggested that trials of HES therapy were of heterogeneous design [11]. Some of these studies had delayed enrollment of patients and used HES not only in the early phase of resuscitation [11]. The indications for fluid resuscitation may not have been standardized and the amount may have been above the recommended dose [11]. In contrast, the CRISTAL trial that compared any

\section{Springer}


crystalloid to any colloid in ICU patients with hypotension, hypovolemia, and tissue hypoperfusion found no difference in the primary endpoint 28-day mortality or need for renal replacement therapy (RRT) $[11,12]$. There were differences in secondary endpoints favoring colloids, including shorter duration mechanical ventilation and cardiovascular support and lower 90-day survival [12]. However, the trial had a higher risk of bias [13], adding to the HES controversy $[9,14,15]$.

In addition to the debates regarding intravenous fluids, recent papers reflected the uncertainties regarding nutritional support in critically ill patients. The 2017 European Society of Intensive Care Medicine (ESICM) clinical practice guidelines for early enteral nutrition (EN started within $48 \mathrm{~h}$ ) included 17 recommendations supporting early EN and seven recommendations supporting delayed EN [16]. The guidelines suggested delaying EN in critically ill patients with uncontrolled shock, uncontrolled hypoxemia and acidosis, uncontrolled upper GI bleeding, gastric aspirate in excess of $500 \mathrm{~mL} / 6 \mathrm{~h}$, bowel ischemia, bowel obstruction, abdominal compartment syndrome, and high-output fistula without distal feeding access [16]. All recommendations were graded as weak because of the low quality of evidence, with several based only on expert opinion [16].

Along this line, an expert panel outlined a roadmap for research agenda in nutrition and metabolism [17]. Recent randomized trials have challenged several concepts, including the notion that energy expenditure must be met universally in all critically ill patients during the acute phase of critical illness by the use of EN or parenteral nutrition (PN) [17]. Current literature leaves uncertainties in nutritional support including energy expenditure and monitoring of nutritional effects across patients with different nutritional risks, substrate requirements, the interrelationship between nutrition and functional recovery, management of intestinal and gastric feeding intolerance, and immune-modulating nutrition [17]. The panel prioritized the top 10 studies for the coming next 10 years. The optimal protein dose combined with mobilization during the acute phase and post-acute phase of critical illness was considered a high research priority [17].

Another aspect related to the gastrointestinal function in critically ill patients, stress ulcer prophylaxis (SUP) with proton pump inhibitors (PPIs) and histamine-2 receptor antagonists, has been questioned lately [18]. SUP is recommended in ICU patients at risk for gastrointestinal bleeding and has become a measure of quality of care. However, there is increasing evidence to suggest that PPIs are associated with increased risk of nosocomial pneumonia and Clostridium difficile infections [18]. Two randomized trials are comparing PPI to placebo in adult ICU patients. The SUP-ICU (Stress Ulcer Prophylaxis in the Intensive Care Unit) trial has been completed and showed that mortality at 90 days and the number of clinically important events were similar in those assigned to pantoprazole and those assigned to placebo $[19,20]$. The REVISE (Re-Evaluating the Inhibition of Stress Erosions: Gastrointestinal Bleeding in ICU) trial has completed a feasibility stage but the main trial has not started [21]. The PEPTIC (Proton pump inhibitors vs. histamine-2 rEceptor blockers for ulcer Prophylaxis Therapy in the Intensive Care unit) trial is a cluster-randomized crossover trial comparing PPI to histamine- 2 receptor antagonists [18].

Recent clinical trials have resulted in major advances in fluid therapy and nutritional support in critically ill patients. The future focus will continue to be addressing high priority research questions by well-designed and adequately powered clinical trials.

\footnotetext{
Author details

1 Intensive Care Department, King Abdulaziz Medical City, College of Medicine, King Saud Bin Abdulaziz University for Health Sciences and King Abdullah International Medical Research Center, MC 1425, P.O. Box 22490, 11426 Riyadh, Saudi Arabia. ${ }^{2}$ Department of Intensive Care, Rigshospitalet, University of Copenhagen, Copenhagen, Denmark.
}

Compliance with ethical standards

Conflicts of interest

The authors declare that they have no competing interests.

Received: 30 September 2018 Accepted: 19 October 2018 Published online: 5 November 2018

\section{References}

1. Rhodes A, Evans LE, Alhazzani W, Levy MM, Antonelli M, Ferrer R, Kumar A, Sevransky JE, Sprung CL, Nunnally ME, Rochwerg B, Rubenfeld GD, Angus DC, Annane D, Beale RJ, Bellinghan GJ, Bernard GR, Chiche JD, Coopersmith C, De Backer DP, French CJ, Fujishima S, Gerlach H, Hidalgo JL, Hollenberg SM, Jones AE, Karnad DR, Kleinpell RM, Koh Y, Lisboa TC, Machado FR, Marini JJ, Marshall JC, Mazuski JE, McIntyre LA, McLean AS, Mehta S, Moreno RP, Myburgh J, Navalesi P, Nishida O, Osborn TM, Perner A, Plunkett CM, Ranieri M, Schorr CA, Seckel MA, Seymour CW, Shieh L, Shukri KA, Simpson SQ, Singer M, Thompson BT, Townsend SR, Van der Poll T, Vincent JL, Wiersinga WJ, Zimmerman JL, Dellinger RP (2017) Surviving Sepsis Campaign: international guidelines for management of sepsis and septic shock: 2016. Intensive Care Med 43(3):304-377. https:// doi.org/10.1007/s00134-017-4683-6

2. Machado FR, Levy MM, Rhodes A (2017) Fixed minimum volume resuscitation: pro. Intensive Care Med 43(11):1678-1680. https://doi. org/10.1007/s00134-016-4590-2

3. Perner A, Singer M (2017) Fixed minimum fluid volume for resuscitation: con. Intensive Care Med 43(11):1681-1682. https://doi.org/10.1007/s0013 4-016-4581-3

4. Maitland K, Kiguli S, Opoka RO, Engoru C, Olupot-Olupot P, Akech SO, Nyeko R, Mtove G, Reyburn H, Lang T, Brent B, Evans JA, Tibenderana JK, Crawley J, Russell EC, Levin M, Babiker AG, Gibb DM, FEAST Trial Group (2011) Mortality after fluid bolus in African children with severe infection. N Engl J Med 364(26):2483-2495. https://doi.org/10.1056/NEJMoa1 101 549 
5. Reinhart K, Perner A, Sprung CL, Jaeschke R, Schortgen F, Johan Groeneveld AB, Beale R, Hartog CS, European Society of Intensive Care Medicine (2012) Consensus statement of the ESICM task force on colloid volume therapy in critically ill patients. Intensive Care Med 38(3):368-383. https://doi.org/10.1007/s00134-012-2472-9

6. Myburgh JA, Finfer S, Bellomo R, Billot L, Cass A, Gattas D, Glass P, Lipman J, Liu B, McArthur C, McGuinness S, Rajbhandari D, Taylor CB, Webb SA, CHEST Investigators, Australian and New Zealand Intensive Care Society Clinical Trials Group (2012) Hydroxyethyl starch or saline for fluid resuscitation in intensive care. N Engl J Med 367(20):1901-1911. https://doi. org/10.1056/NEJMoa1209759

7. Perner A, Haase N, Guttormsen AB, Tenhunen J, Klemenzson G, Aneman A, Madsen KR, Moller MH, Elkjaer JM, Poulsen LM, Bendtsen A, Winding R, Steensen M, Berezowicz P, Soe-Jensen P, Bestle M, Strand K, Wiis J, White JO, Thornberg KJ, Quist L, Nielsen J, Andersen LH, Holst LB, Thormar K, Kjaeldgaard AL, Fabritius ML, Mondrup F, Pott FC, Moller TP, Winkel P, Wetterslev J, 6S Trial Group, Scandinavian Critical Care Trials Group (2012) Hydroxyethyl starch 130/0.42 versus Ringer's acetate in severe sepsis. N Engl J Med 367(2):124-134. https://doi.org/10.1056/NEJMoa1204242

8. European Medicines Agency (2018) Hydroxyethyl starch solutions for infusion. http://www.emaeuropaeu/ema/indexjsp?curl=pages/medic ines/human/referrals/Hydroxyethyl_starch-containing_solutions/human _referral_prac_000012jsp\&mid =WC0b01ac05805c516f. Accessed 24 Sept 2018

9. Frank G (2018) HES: time to change my mind? Intensive Care Med 44(9):1577-1578. https://doi.org/10.1007/s00134-018-5124-x

10. Wiedermann CJ, Bellomo R, Perner A (2017) Is the literature inconclusive about the harm from HES? No. Intensive Care Med 43(10):1523-1525. https://doi.org/10.1007/s00134-016-4275-x

11. Ertmer C, Annane D, Van Der Linden P (2017) Is the literature inconclusive about the harm from HES? Yes. Intensive Care Med 43(10):1520-1522. https://doi.org/10.1007/s00134-016-4278-7

12. Annane $D$, Siami $S$, Jaber $S$, Martin $C$, Elatrous $S$, Declere AD, Preiser JC Outin H, Troche G, Charpentier C, Trouillet JL, Kimmoun A, Forceville X, Darmon M, Lesur O, Reignier J, Abroug F, Berger P, Clec'h C, Cousson J, Thibault L, Chevret S, CRISTAL Investigators (2013) Effects of fluid resuscitation with colloids vs crystalloids on mortality in critically ill patients presenting with hypovolemic shock: the CRISTAL randomized trial. JAMA 310(17):1809-1817. https://doi.org/10.1001/jama.2013.280502

13. Perner A, Haase N, Wetterslev J (2014) Mortality in patients with hypovolemic shock treated with colloids or crystalloids. JAMA 311(10):1067. https://doi.org/10.1001/jama.2014.830

14. Schetz M, Shaw AD, Vincent JL (2017) Is the literature inconclusive about the harm of HES? We are not sure. Intensive Care Med 43(10):1526-1528. https://doi.org/10.1007/s00134-016-4329-0
15. Doshi P (2018) EMA recommendation on hydroxyethyl starch solutions obscured controversy. BMJ 360:k1287. https://doi.org/10.1136/bmj.k1287

16. Reintam Blaser A, Starkopf J, Alhazzani W, Berger MM, Casaer MP, Deane AM, Fruhwald S, Hiesmayr M, Ichai C, Jakob SM, Loudet Cl, Malbrain ML, Montejo Gonzalez JC, Paugam-Burtz C, Poeze M, Preiser JC, Singer P, van Zanten AR, De Waele J, Wendon J, Wernerman J, Whitehouse T, Wilmer A, Oudemans-van Straaten HM, Working Group on Gastrointestinal Function (2017) Early enteral nutrition in critically ill patients: ESICM clinical practice guidelines. Intensive Care Med 43(3):380-398. https://doi. org/10.1007/s00134-016-4665-0

17. Arabi YM, Casaer MP, Chapman M, Heyland DK, Ichai C, Marik PE, Martindale RG, McClave SA, Preiser JC, Reignier J, Rice TW, Van den Berghe G, van Zanten AR, Weijs PJ (2017) The intensive care medicine research agenda in nutrition and metabolism. Intensive Care Med. https://doi. org/10.1007/s00134-017-4711-6

18. Marker S, Krag M, Moller MH (2017) What's new with stress ulcer prophylaxis in the ICU? Intensive Care Med 43(8):1132-1134. https://doi. org/10.1007/s00134-017-4733-0

19. Krag M, Marker S, Perner A, Wetterslev J, Wise MP, Schefold JC, Keus F, Guttormsen AB, Bendel S, Borthwick M, Lange T, Rasmussen BS, Siegemund M, Bundgaard H, Elkmann T, Jensen JV, Nielsen RD, Liboriussen L, Bestle MH, Elkjaer JM, Palmqvist DF, Backlund M, Laake JH, Badstolokken PM, Gronlund J, Breum O, Walli A, Winding R, Iversen S, Jarnvig IL, White JO, Brand B, Madsen MB, Quist L, Thornberg KJ, Moller A, Wiis J, Granholm A, Anthon CT, Meyhoff TS, Hjortrup PB, Aagaard SR, Andreasen JB, Sorensen CA, Haure P, Hauge J, Hollinger A, Scheuzger J, Tuchscherer D, Vuilliomenet T, Takala J, Jakob SM, Vang ML, Paelestik KB, Andersen KLD, van der Horst ICC, Dieperink W, Fjolner J, Kjer CKW, Solling C, Solling CG, Karttunen J, Morgan MPG, Sjobo B, Engstrom J, Agerholm-Larsen B, Moller MH, group S-It (2018) Pantoprazole in Patients at Risk for Gastrointestinal Bleeding in the ICU. N Engl J Med. https://doi.org/10.1056/NEJMoa1714 919

20. Krag M, Perner A, Wetterslev J, Wise MP, Borthwick M, Bendel S, Pelosi P, Keus F, Guttormsen AB, Schefold JC, Moller MH, SUP-ICU Investigators (2016) Stress ulcer prophylaxis with a proton pump inhibitor versus placebo in critically ill patients (SUP-ICU trial): study protocol for a randomised controlled trial. Trials 17(1):205. https://doi.org/10.1186/s1306 3-016-1331-3

21. Alhazzani W, Guyatt G, Alshahrani M, Deane AM, Marshall JC, Hall R, Muscedere J, English SW, Lauzier F, Thabane L, Arabi YM, Karachi T, Rochwerg B, Finfer S, Daneman N, Alshamsi F, Zytaruk N, Heel-Ansdell D, Cook D, Canadian Critical Care Trials Group (2017) Withholding pantoprazole for stress ulcer prophylaxis in critically ill patients: a pilot randomized clinical trial and meta-analysis. Crit Care Med 45(7):1121-1129. https:// doi.org/10.1097/CCM.0000000000002461 